\title{
The pharmacokinetics of an oral form of carbenicillin in patients with renal failure
}

\author{
R. R. BAILEY* \\ M.D.(N.Z.), M.R.A.C.P., M.R.C.P. \\ J. B. EASTWOOD \\ M.B., B.S., M.R.C.P. \\ Department of Medicine, Charing Cross Hospital Medical School, London, W.6 \\ R. B. VAUGHAN \\ M.B., B.S., Ph.D. \\ Clinical Research Department, Pfizer Limited
}

\begin{abstract}
Summary
An orally active ester of carbenicillin was administered to patients with varying degrees of renal dysfunction. The peak serum levels and serum half-life were found to be increased in patients with renal failure. Urine levels, however, in these patients were above the minimum inhibitory concentration for the majority of urinary tract pathogens.
\end{abstract}

\section{Introduction}

Patients with renal failure frequently require treatment for bacterial infections of the urinary tract. In making the choice of antibacterial therapy it is important to know each patient's ability to excrete the drug under consideration. This will determine whether therapeutic levels are attained in the urine without high and possibly dangerous plasma levels being reached.

The indanyl ester of carbenicillin (CP-15,464) is acid-stable and absorbed following oral administration. Following absorption the ester is rapidly hydrolysed to yield carbenicillin (Therapeutics Research Division, Pfizer Limited-personal communication). In a series of twenty-seven cases of bacteriuria in non-pregnant women caused by the common urinary pathogens, Bailey \& Koutsaimanis (1972) obtained clearance of the urine in sixteen. Furthermore, these authors suggested that the ester might be particularly useful in the treatment of bacteriuria in which the infecting organism was Pseudomonas aeruginosa or one of the more troublesome members of the genus Proteus and, because of its freedom from serious toxic effects, valuable in patients with impaired renal function.

The present study was undertaken to assess the effects of various degrees of renal impairment and haemodialysis on the serum half-life and urinary excretion of carbenicillin following oral administra-

\footnotetext{
* Present address: Department of Renal Medicine, Christchurch Hospital, Christchurch, New Zealand.
}

tion of the indanyl ester. Serum levels were also measured in patients with normal renal function who were receiving a full therapeutic dose.

\section{Patients and methods}

\section{Patients with renal failure not on dialysis}

Seven patients with various degrees of renal impairment were studied. All patients were given two $0 \cdot 5$-g film-coated tablets of ester $1 \frac{1}{2} \mathrm{hr}$ after a hospital breakfast. Samples of venous blood were collected 1, $2,3,6,12$ and $24 \mathrm{hr}$ after administration of the compound. Urine was collected between 0 and 30 3 and 6, 6 and 12, 12 and 18 and 18 and $24 \mathrm{hr}$ afte taking the carbenicillin ester.

\section{Anephric patients studied between haemodialyses}

Two anephric patients were studied. They were being treated with twice weekly maintenance haemodialysis using a single pass system with a modified Kiil dialyser and cuprophane membranes (P.T. 150). $1 \mathrm{~g}$ of the ester was given on the day following a 14-hr dialysis and samples of blood were taken as above.

\section{Patients studied during haemodialyses}

Nine patients (five anephric) were studied during a 14-hr haemodialysis. $1 \mathrm{~g}$ of the ester was given $1 \mathrm{hr}$ before starting dialysis. Samples of blood were taken from the shunt immediately before connection to the dialyser-i.e. $1 \mathrm{hr}$ after antibiotic administration-at the midpoint and at the end of the 14-hr dialysis.

\section{Patients receiving multiple doses}

Three patients with normal renal function received $1 \mathrm{~g}$ of the ester every $6 \mathrm{hr}$, for a total of twenty-eight doses. Blood was taken 1 and $5 \mathrm{hr}$ after several doses distributed throughout the dosage period. The urinary excretion of the compound was measured in two of these patients.

All blood samples were allowed to clot, then centrifuged at $10,000 \mathrm{rpm}$ for $15 \mathrm{~min}$ and the serum 
stored at $-20^{\circ} \mathrm{C}$. After measurement of the urine volume for each collection period an aliquot of each was stored without preservative at $-20^{\circ} \mathrm{C}$. Assays of carbenicillin were carried out by a large plate microbiological assay technique using Pseudomonas aeruginosa N.C.T.C. 10490 as the test organism.

Serum urea, serum creatinine and twenty-four endogenous creatinine clearance were estimated the day before and the day after the study in patients not on haemodialysis.

Patients with renal failure but not on dialysis were grouped according to the glomerular filtration rate (GFR) as measured by the 24-hr creatinine clearance:

Group I-GFR $5 \mathrm{ml} / \mathrm{min}$ (one patient).

Group II-GFR 10-20 ml/min (four patients).

Group III-GFR $23 \mathrm{ml} / \mathrm{min}$ (one patient).

Group IV-GFR $59 \mathrm{ml} / \mathrm{min}$ (one patient).

The serum half-life value for each patient was estimated by the method of least squares.

\section{Results}

Patients with renal failure not on dialysis and anephric patients between dialyses

Serum levels of carbenicillin. The mean peak serum concentration of carbenicillin for each group of patients together with that of a group of twenty-four normal volunteers given a single oral dose of $1 \mathrm{~g}$ of the ester are given in Table 1 . With diminishing renal function higher mean serum concentrations of carbenicillin were obtained (Fig. 1). In the anephric patients however, the mean peak serum concentrations were not as high as for several patients who had moderate to advanced renal failure. Furthermore, in those patients with a GFR of around $20 \mathrm{ml} / \mathrm{min}$ or less there was a marked delay in the time of appearance of the peak serum level. The time of its appearance approaching that seen in the anephric patients studied between dialyses, i.e. $6 \mathrm{hr}$ after dosing (Table 1). The relationship of the serum half-life of carbenicillin to the GFR is shown in Fig. 2. The serum half-life for the two anephric patients was 22.7 and $18.5 \mathrm{hr}$ respectively.

Urinary excretion of carbenicillin. The concentration of carbenicillin in the urine over several periods of collection and the amount excreted, expressed as a percentage of both the administered dose of the ester and the available carbenicillin, following the administration of $1 \mathrm{~g}$ of the ester to patients with various degrees of renal impairment and a group of normal volunteers are given in Table 2 . Only when the GFR drops below $20 \mathrm{ml} / \mathrm{min}$ does the concentration of carbenicillin and the amount excreted fall below that of the' normal individual.

Effect of haemodialysis on serum levels of carbenicillin. Of the nine patients studied whilst on haemodialysis, carbenicillin was detected in the serum of seven at the end of dialysis. The mean serum half-life, computed from the values obtained after 7 and

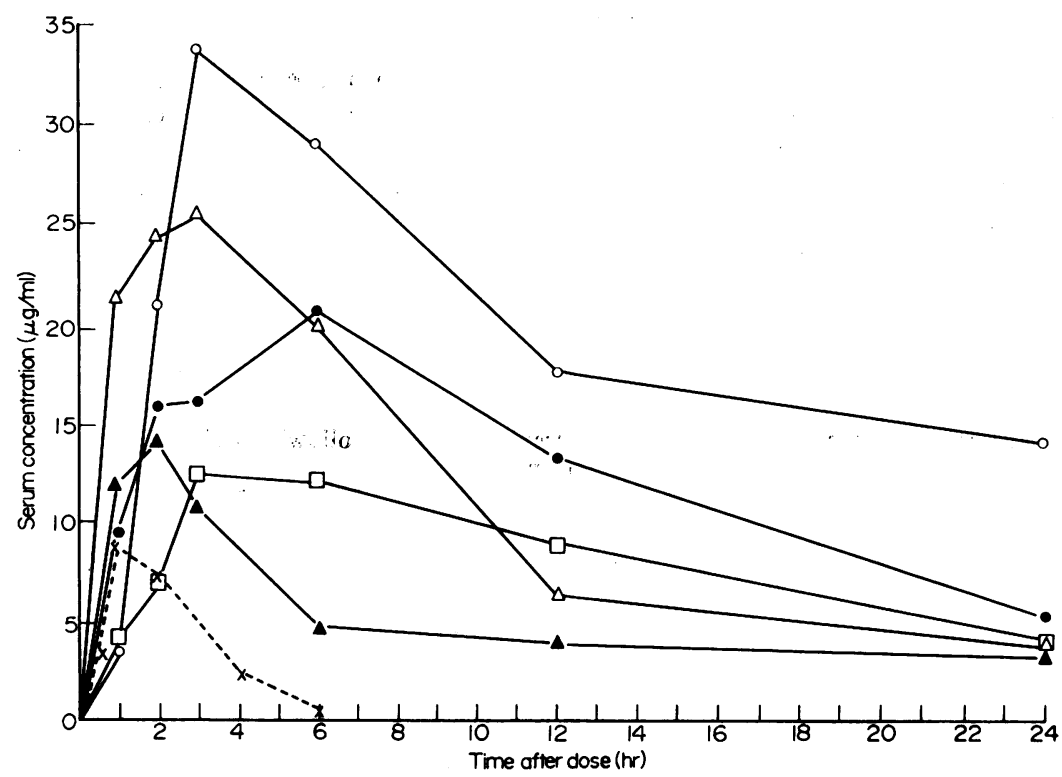

FIG. 1. The mean serum concentrations $(\mu \mathrm{g} / \mathrm{ml})$ of carbenicillin in normal volunteers and patients with reduced glomerular filtration rates following a single $1 \mathrm{~g}$ oral dose of the indanyl ester of carbenicillin (CP-15,464). $\times \cdots \times$, Normal (twenty-four); $0-O$, GFR $5 \mathrm{ml} / \mathrm{min}$; - - GFR 10-20 ml/min (four); $\triangle-\triangle$, GFR $23 \mathrm{ml} / \mathrm{min} ; \triangle-\Delta$, GFR $59 \mathrm{ml} / \mathrm{min} ; \square-\square$, Anephric. 
TABI.E 1. The effect of the glomerular filtration rate on the mean peak serum concentration of carbenicillin and the time of its appearance following a single $1 \mathrm{~g}$ dose of the indanyl ester of carbenicillin (CP-15,464)

\begin{tabular}{cccc}
\hline $\begin{array}{c}\text { GFR } \\
(\mathrm{ml} / \mathrm{min})\end{array}$ & $\begin{array}{c}\text { No. of } \\
\text { subjects }\end{array}$ & $\begin{array}{c}\text { Mean peak serum } \\
\text { concentration } \\
(\mu \mathrm{g} / \mathrm{ml})\end{array}$ & $\begin{array}{c}\text { Time of } \\
\text { appearance } \\
\text { after dose } \\
(\mathrm{hr})\end{array}$ \\
\hline $\begin{array}{c}\text { Anephric } \\
5\end{array}$ & 2 & $12 \cdot 2$ & 6 \\
$10-20$ & 1 & $33 \cdot 5$ & $3^{*}$ \\
& 4 & $23 \cdot 8$ & $2-6 \dagger$ \\
23 & 1 & $(\mathrm{SD} 5 \cdot 6)$ & 3 \\
59 & 1 & $25 \cdot 3$ & 2 \\
Normal & 24 & $14 \cdot 2$ & 1 \\
volunteers & & $8 \cdot 9$ & \\
\hline
\end{tabular}

* Plateau effect between 3 and $6 \mathrm{hr}$ although actual peak occurred at $3 \mathrm{hr}$.

$\dagger$ Plateau effect between 2 and $6 \mathrm{hr}$ in two patients in whom actual peak was at $2 \mathrm{hr}$.

¥ Study by Therapeutics Research Division, Pfizer Limited.

$14 \mathrm{hr}$ dialysis, for shese seven patients was $10.5 \mathrm{hr}$ (range 6.0-21.3; SD 5.1) although in five of them it was less than this mean. The serum concentration at the end of dialysis (15 $\mathrm{hr}$ after the dose) in six of these seven patients was between 4 and $5 \mu \mathrm{g} / \mathrm{ml}$. This concentration of carbenicillin was approximately half that found $15 \mathrm{hr}$ after administration of $1 \mathrm{~g}$ of the ester to two anephric patients studied between dialyses.

Serum levels and urinary excretion of carbenicillin in patients with normal renal function receiving a full therapeutic course of CP-15,464

In three women, serum levels of carbenicillin were measured 1 and/or $5 \mathrm{hr}$ after administration of a dose during a full therapeutic course of $1 \mathrm{~g}$ of the ester every $6 \mathrm{hr}$ for 1 week. No drug accumulation occurred in the serum although in one patient (M.L.) the levels obtained $1 \mathrm{hr}$ after a dose on days 5 and 7 were higher than those for the initial 4 days of treatment (Table 3).

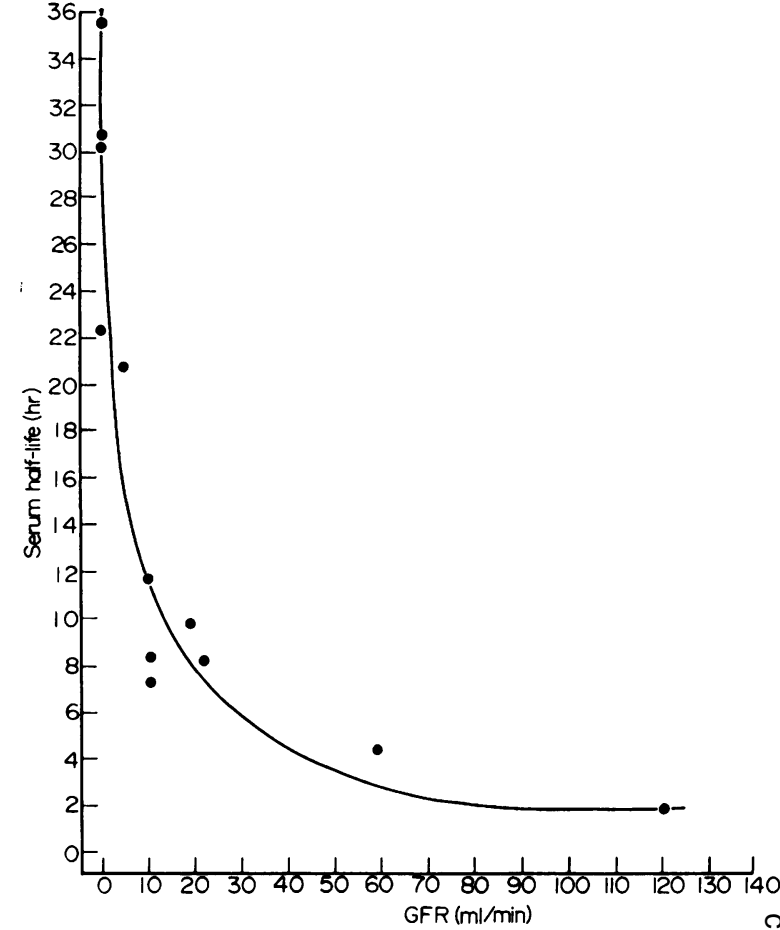

FIG. 2. Relationship of serum half-life to glomerular filtration rate.

In two of these three patients, urine was collected during the treatment period. In both women the amount of carbenicillin excreted in each $24-\mathrm{hr}$ period did not vary significantly, i.e. for R.B. $27 \cdot 7 \%$ (SD 2.7 ) of administered dose, $36.2 \%$ (SD 3.6) of available carbenicillin; for M.L. $21.7 \%$ (SD 3.9) and $28.4 \%$ (SD 5.0 ) respectively. The concentration of the drug in the urine ranged from 374 to $2075 \mu \mathrm{g} / \mathrm{ml}$ (R.B.) and 183-1575 $\mu \mathrm{g} / \mathrm{ml}$ (M.L.).

TABLE 2. The concentration and amount of carbenicillin excreted over $24 \mathrm{hr}$ following a single $1 \mathrm{~g}$ dose of the indanyl ester of carbenicillin (CP-15,464)

\begin{tabular}{|c|c|c|c|c|c|c|c|}
\hline \multirow[b]{2}{*}{$\begin{array}{c}\text { GFR } \\
(\mathrm{ml} / \mathrm{min})\end{array}$} & \multirow[b]{2}{*}{$\begin{array}{l}\text { No. of } \\
\text { subjects }\end{array}$} & \multicolumn{2}{|c|}{$\begin{array}{l}\text { Amount of carbenicillin } \\
\text { excreted in } 24 \mathrm{hr} \\
\text { expressed as percentage of: }\end{array}$} & \multicolumn{4}{|c|}{$\begin{array}{l}\text { Concentration }(\mu \mathrm{g} / \mathrm{ml}) \text { of } \\
\text { carbenicillin in urine over } \\
\text { collection periods }(\mathrm{hr})\end{array}$} \\
\hline & & $\begin{array}{c}\text { Administered } \\
\text { dose }\end{array}$ & $\begin{array}{c}\text { Available } \\
\text { carbenicillin }\end{array}$ & $0-3$ & $3-6$ & $6-12$ & $12-24$ \\
\hline $\begin{array}{c}5 \\
10-20\end{array}$ & 1 & $\begin{array}{c}5 \cdot 7 \\
14 \cdot 6 \\
(S D 7 \cdot 1)\end{array}$ & $\begin{array}{c}7 \cdot 5 \\
19 \cdot 1 \\
(S D 9 \cdot 4)\end{array}$ & $\begin{array}{l}50 \\
73\end{array}$ & $\begin{array}{l}65 \\
88\end{array}$ & $\begin{array}{l}44 \\
31\end{array}$ & $\begin{array}{l}29 \\
37\end{array}$ \\
\hline $\begin{array}{c}23 \\
59 \\
\text { Normal } \\
\text { volunteers }\end{array}$ & $\begin{array}{c}1 \\
1 \\
12 \dagger\end{array}$ & $\begin{array}{c}36 \cdot 3 \\
31 \cdot 2 \\
31 \cdot 2 \\
(\mathrm{SD} 11 \cdot 9)\end{array}$ & $\begin{array}{c}47 \cdot 5 \\
40 \cdot 8 \\
40 \cdot 8 \\
(S D 15 \cdot 5)\end{array}$ & \multicolumn{2}{|c|}{$\begin{array}{c}962 \\
\text { (SD 474) }\end{array}$} & \multicolumn{2}{|c|}{$\begin{array}{c}34 \\
(S D ~ 130)\end{array}$} \\
\hline
\end{tabular}

* Urine not collected from one of four patients in this group.

† Urine only collected from male volunteers in group of twenty-four. Study by Therapeutics Research Division, Pfizer Limited. 
TABLE 3. Individual serum concentrations of carbenicillin following the oral administration of $1 \mathrm{~g}$ of the indanyl ester of carbenicillin (CP-15,464) for a total of twenty-eight doses in three patients with normal renal function

Serum concentration $(\mu \mathrm{g} / \mathrm{ml})$

Day of treatment course and hours after administration of previous dose

\begin{tabular}{|c|c|c|c|c|c|c|c|c|c|c|c|c|c|c|}
\hline \multirow[t]{2}{*}{ Patient } & \multicolumn{2}{|c|}{ Day 1} & \multicolumn{2}{|c|}{ Day 2} & \multicolumn{2}{|c|}{ Day 3} & \multicolumn{2}{|c|}{ Day 4} & \multicolumn{2}{|c|}{ Day 5} & \multicolumn{2}{|c|}{ Day 6} & \multicolumn{2}{|c|}{ Day 7} \\
\hline & 1 & 5 & 1 & 5 & 1 & 5 & 1 & 5 & 1 & 5 & 1 & 5 & 1 & 5 \\
\hline R.B. & $7 \cdot 0$ & $3 \cdot 7$ & $6 \cdot 8$ & - & $5 \cdot 6$ & - & $6 \cdot 1$ & 3.4 & $6 \cdot 2$ & - & $5 \cdot 5$ & $3 \cdot 2$ & $9 \cdot 8$ & - \\
\hline M.L. & $7 \cdot 4$ & $2 \cdot 9$ & $3 \cdot 3$ & - & $4 \cdot 3$ & - & 5.0 & $3 \cdot 1$ & $16 \cdot 8$ & - & - & - & $12 \cdot 4$ & - \\
\hline B.J. & - & - & - & - & - & $2 \cdot 9$ & $2 \cdot 8$ & $3 \cdot 2$ & $3 \cdot 3$ & - & - & - & - & - \\
\hline
\end{tabular}

\section{Side-effects}

The only side-effect observed in this study was seen in one woman with normal renal function who complained of after-taste and heartburn whilst taking the full twenty-eight dose course.

\section{Discussion}

The indanyl ester of carbenicillin $(\mathrm{CP}-15,464)$ is acid-stable. Following oral administration it is rapidly absorbed and hydrolysed to yield carbenicillin. The indanol moiety is rapidly converted to glucuronide and sulphate ester conjugates and cleared by the kidneys (Therapeutics Research Division, Pfizer Limited-personal communication).

In twenty-four normal volunteers the peak serum concentration of carbenicillin occurred $1-2 \mathrm{hr}$ after oral administration of the indanyl ester. The mean serum concentration of carbenicillin produced by an oral dose of $1 \mathrm{~g}$ of the ester is similar to that obtained following an intramuscular dose of $0.25 \mathrm{~g}$ of carbenicillin (Knudsen, Rolinson and Sutherland, 1967). In twelve of the volunteers, urine was collected for $24 \mathrm{hr}$ following the dose of the ester. The concentration of carbenicillin in the urine 2-6 hr after drug administration exceeded $500 \mu \mathrm{g} / \mathrm{ml}$ in eleven of the twelve volunteers, while in six of them the concentration was over $1000 \mu \mathrm{g} / \mathrm{ml}$ (Therapeutics Research Division, Pfizer Limited-personal communication). This concentration greatly exceeds the minimum inhibitory concentration of the great majority of organisms responsible for urinary tract infections. A recent trial reported from this department showed that the ester was effective in eradicating bacteriuria from sixteen of twenty-seven women with normal renal function and a radiologically normal urinary tract (Bailey \& Koutsaimanis, 1972).

The results of the present study demonstrate that with a normal urinary tract and normal renal function accumulation of carbenicillin does not occur in the serum of patients receiving a dosage of $1 \mathrm{~g}$ of the indanyl ester orally every $6 \mathrm{hr}$. In patients with impaired renal function however, a considerably higher peak serum concentration of carbenicillin occurs and there is marked prolongation of the serum half-life of the drug. The time taken to reach the peak level in the serum is delayed in those patients whose renal function is impaired. In renal failure the amount of carbenicillin excreted in the urine diminishes as the GFR deteriorates. However, even in severe renal failure, urine concentrations of carbenicillin exceed the minimum inhibitory concentration for the majority of urinary tract pathogens.

In previous work from this department the mean serum half-life of eight patients receiving $1 \mathrm{~g}$ of carbenicillin intravenously between haemodialyses was $12.5 \mathrm{hr}$. The half-life was reduced to a mean of $4.5 \mathrm{hr}$ in three of these patients studied during haemodialysis (Eastwood \& Curtis, 1968). In the present study the mean serum half-life of carbenicillin in patients undergoing haemodialysis was considerably greater at $10.5 \mathrm{hr}$. However, the serum levels obtained after the oral preparation were much lower than those produced by the parenterally administered drug.

In view of the high levels of carbenicillin obtained in the urine of normal subjects and in patients with a normal GFR, it may be possible to reduce the daily dosage from 4 to $2 \mathrm{~g}$ of CP-15,464 without reducing the antibacterial effect in the urine. This may minimize the mild side-effects referable to the gastrointestinal tract previously reported (Wallace et al., 1971; Bran, Karl \& Kaye, 1971; Bailey \& Koutsaimanis, 1972). Only when the GFR is below $20 \mathrm{ml} / \mathrm{min}$ should the regimen be modified for the treatment of bacteriuria. For patients with a GFR below 20 $\mathrm{ml} / \mathrm{min}$ therapeutically effective levels in the urine may be obtained and maintained throughout the day by as little as $1 \cdot 0-1 \cdot 5 \mathrm{~g}$ daily. The factor limiting dosage in any such patient would be accumulation of carbenicillin in the serum of that patient. The effects of renal failure on the clearance of the indanol moiety require further investigation before firm recommendations as to dosage can be given.

Indanyl carbenicillin appears to be free from serious toxic effects and yields therapeutic levels of cabenicillin in the urine even of patients with severe renal failure. It therefore seems to be a valuable addition to the agents already available for the treatment of urinary tract infections. 


\section{Acknowledgment}

The serum and urine assays were carried out by the staff of the Clinical Microbiology Department, Pfizer Limited, Sandwich, Kent.

\section{References}

Bailey, R.R. \& Koutsaimanis, K.G. (1972) Oral administration of a new carbenicillin in the treatment of urinary tract infections. British Journal of Urology, 44, 235.

BRAN, J.L., KARL, D.M. \& KAYE, D. (1971) Human pharmacology and clinical evaluation of an oral carbenicillin preparation. Clinical Pharmacology and Therapeutics, 12, 525.

EASTwood, J.B. \& CuRTIS, J.R. (1968) Carbenicillin administration in patients with severe renal failure. British Medical Journal, 1, 486.

KnudSEn, E.T., Rolinson, G.N. \& Sutherland, R. (1967) Carbenicillin: A new semisynthetic penicillin active against Pseudomonas pyocyanea. British Medical Journal, 3, 75.

Wallace, J. F., Atlas, E., Bear,- D.M., Brown, N.K., Clark, H. \& TURCK, M. (1970) Evaluation of an indanyl ester of carbenicillin. Antimicrobial Agents and Chemotherapy, 223. 